\title{
Source-sink relationships in maize grown in a cool-temperate area
}

\author{
SA Uhart, FH Andrade \\ EEA Balcarce, Instituto Nacional de Tecnologia Agropecuaria (INTA), Facultad de Ciencias Agrarias, \\ Univ Nac de Mar del Plata, CC 276 (7620) Balcarce, Buenos Aires, Argentina
}

(Received 12 July 1991; accepted 29 September 1991)

\begin{abstract}
Summary - The objectives of this work were to: a), establish whether maize yield in Balcarce (Argentina $37^{\circ} 45^{\prime} L S$; $58^{\circ} 18^{\prime} \mathrm{LO}$ ) is limited by the source of assimilates or by the number and size of the reproductive sinks; b), establish whether hybrids that differ in length of the growing cycle present differences in their source-sink relationships; $c$ ), determine to what extent the evolution of carbohydrate $(\mathrm{CH})$ reserves in the plant is modified by different source-sink relationships. The experiment was conducted at Balcarce over a 2-year period with 2 hybrids (short season: SPS 240, long season: D2F11). The treatments consisted of 2 levels of source reduction ( 45 and $55 \%$ shading during the grain filling period, GFS), 2 levels of reproductive sink reduction (45 and 55\% shading aroung flowering, FS) and an unshaded control. The different shading treatments had a constant reduction of radiation with variable shading duration (30-38 days). The results indicate the existence of a colimitation by source of assimilates and reproductive sinks because grain yield dropped similarly in response to shading during the flowering and the grain filling periods. FS reduced grain number/unit area and slightly increased 1000 kernel weight. GFS reduced 1000 kernel weight, and to a lesser extent grain number/unit area. The study of dry matter and $\mathrm{CH}$ accumulation or remobilization in response to shading at the R3-R5 period, relative to those of the control treatment, was useful to indicate trends toward sink or source limitations. Relative to the control, shading at any period produced a decrease in stem $\mathrm{CH}$ content during the treatment period. During the post-shading period, the FS treatments presented a greater $\mathrm{CH}$ accumulation in stems than the control. This is explained by the decrease in reproductive sink number that produced a drop in their demand of $\mathrm{CH}$ and by the increased importance of the stem as an alternative sink for assimilates. GFS treatments produced a strong increase in $\mathrm{CH}$ remobilization rate from stem during the treatment period. The 2 hybrids did not show statistically significant differences in their source-sink relationship. Nevertheless, a tendency toward a source limitation was evident in the long season hybrid.
\end{abstract}

Zea mays = maize $/$ source-sink relationships $/$ carbohydrate remobilization

Résumé - Rapports source-puits du maïs dans une région tempérée-froide. Les objectifs du travail ont été :

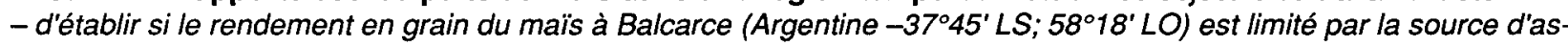
similats ou par le nombre et la taille des puits reproductifs;

- d'établir si les hybrides de différents cycles ont différents rapports source-puits;

- de déterminer dans quelle mesure l'évolution des carbohydrates de réserve (CH) dans la plante est modifiée par les différentes relations source-puits. L'expérience a été conduite à Balcarce pendant 2 années avec 2 hybrides (cycle court : SPS 240; cycle long : D2F11).

Les traitements ont compris 2 niveaux de réduction de source (45 et 55\% d'ombrage artificiel pendant la période de remplissage du grain, GFS), 2 niveaux de réduction des puits reproductifs (45 et $55 \%$ d'ombrage artificiel en floraison, FS), et un témoin sans ombrage artificiel.

Les différents traitements d'ombrage ont eu une réduction constante de rayonnement et une durée de la période d'ombrage variable (30-38 j).

Les résultats indiquent l'existence d'une limitation à la fois par la source d'assimilats et par les puits reproductifs parce que le rendement en grain a diminué de façon similaire en réponse aux traitements d'ombrage pendant la floraison et le remplissage du grain (tableau VI).

FS réduit le nombre de grains/unité de surface et en conséquence, on constate une légère augmentation du poids de 1000 grains. GFS réduit le poids de 1000 grains, et en moindre mesure, le nombre de grains/unité de surface (tableau III).

Le suivi de l'accumulation et de la remobilisation de matière sèche et des $\mathrm{CH}$ en réponse à l'ombrage pendant la période R3-R5 par rapport à celles du traitement témoin, a été utile pour indiquer les tendances vers des limitations par Ta source ou par les puits. L'ombrage à n'importe quelle période produit une réduction de $\mathrm{CH}$ de la tige, par rapport au témoin, pendant le temps d'imposition des traitements. Les traitements FS ont montré pendant la période post- 
ombrage une plus grande accumulation de $\mathrm{CH}$ dans les tiges que le témoin. Ceci est expliqué par la réduction du nombre de puits reproductifs qui produit une diminution de la demande de $\mathrm{CH}$, mais aussi par l'augmentation de l'importance de la tige comme puits d'assimilats.

Les traitements GFS ont produit une forte augmentation du taux de remobilisation de CH de la tige pendant le temps d'imposition du traitement (figs 3, 5 et 6; tableau IV et V).

Les 2 hybrides n'ont pas montré des différences significatives dans leurs relations source-puits. Cependant l'hybride de cycle long a montré une tendance plus évidente vers la limitation par la source, par une importance plus grande des remobilisations.

\section{Zea mays = maïs $/$ relations source-puits $/$ remobilisation de carbohydrates}

\section{INTRODUCTION}

Limitations of grain yield in crops that are not explained by unfavorable factors such as diseases, nutrient or water deficiencies, etc, may be analyzed in terms of assimilate supply to the developing grain, the source, and the potential of the grains to accomodate assimilates, the sink (Tollenaar, 1977). Among grain crops, the sourcesink relationships have been studied more extensively in wheat and barley (Tollenaar, 1977). Some authors have reported that grain yield was limited by the sink capacity (Bingham, 1967; Evans and Rawson, 1970); others have concluded that yield was limited by the source (Welbank et al, 1966; Simpson, 1968), whereas Fischer (1975) and Stoy (1976) have suggested that both sink and source limitations may occur, and the particular combination of genotype and environment determines which limitation predominates.

Yoshida (1972), in a review, concluded that under favorable climate and adequate nutrient provision it is more likely that the sink limits grain yield of wheat and rye.

Studies on maize conducted in Mexico have shown the importance of the sink limitation on the grain yield (Yamaguchi, 1974; Goldsworthy et al, 1974; Goldsworthy and Coleogrove, 1974).

Similar results have been found in the USA using different research methodologies such as artificial shading (Early et al, 1966, 1967; Prine, 1971), artificial increment of radiation during flowering or grain filling (Schoper et al, 1982), total or partial defoliation and ear removal (Hanway, 1969; Barnett and Pearce, 1983; Jones and Simmons, 1983), and reduction of population density at different stages of plant development (Prine, 1971). In Rhodesia (now Zimbabwe), Allison and Watson (1966) and Allison et al (1975) reported that a large amount of stem dry matter which could be translocated to the grain remains without remobilisation, indicating a sink limitation.
In contrast, Daynard et al (1969) and Hume and Campbell (1972), in Canada, showed that non-defoliated plants had an important carbohydrate $(\mathrm{CH})$ transiocation from stems and husks to the grain during the last moments of grain filling period suggesting a source limitation for grain yield.

Tollenaar and Daynard (1978), in Ontario, varied incident radiation by light enrichment or artificial shading aroung flowering and grain filling. They observed that grain yield was more affected by the alteration of assimilate supply during grain filling than around flowering, and concluded that the source was the prevailing limitation.

In areas such as Ontario where the growing season of maize is restricted by cool temperatures in spring and fall, the source limitation is caused by the precocity of flowering that produces plants with small leaf area, and by the high rate of dry matter accumulation in the grains (trait chosen for areas with short grain filling period) that may cause early leaf senescence (Tollenaar and Daynard, 1982).

Early et al (1967), Hanway (1969), Hicks et al (1977), Barnett and Pearce (1983) and Vasilas and Seif (1985) reported differential hybrid responses to treatments of source or sink limitation. Most of these differences were attributed to duration of life cycle (long vs short).

The objectives of this study were: a) to determine if maize grain yield in Balcarce, Argentina, is limited by the capacity of the reproductive sinks; b) to evaluate the effect of the length of the growing cycle in the source-sink relationships; c) to determine to what extent the evolution of stem $\mathrm{CH}$ is affected by the different source-sink relationships.

The methodology of assimilate reduction during flowering and grain filling (Tollenaar, 1977; Tollenaar and Daynard, 1978) was used, taking into account the considerations made by Tollenaar and Daynard (1978), Lauer (1985) and Early et al $(1966,1967)$ with relation to type and intensity of the treatment. 


\section{MATERIALS AND METHODS}

The experiment was conducted during the 1987/1988 and 1988/1989 growing seasons at the INTA Research Station Balcarce, Buenos Aires, Argentina $\left(37^{\circ} 45^{\prime}\right.$ LS; $58^{\circ} 18^{\prime}$ LO) on a typic Argiudol soil with a minimum effective depth of $1.50 \mathrm{~m}(25.9 \%$ clay; $40 \%$ silt; $34 \%$ sand, and $5.3 \%$ organic matter at a depth of $0-25 \mathrm{~cm}$ ). This study involved two red, flint simple hybrids of maize: Dekalb $2 \mathrm{~F} 11$ (long season, $3300^{\circ} \mathrm{C}$ from emergence to physiological maturity; Ontario method; Brown, 1969) and SPS 240 (short season, $2800^{\circ} \mathrm{C}$ from emergence to physiological maturity; Ontario method; Brown, 1969).

They were sown on 16 October 1987 and 12 October 1988, rows $0.7 \mathrm{~m}$ apart. The population density was 85000 plants/ha in $1987 / 1988$ and 91000 plants/ ha in 1988/1989.

The crop was kept free of weeds, and insect pests were adequately controlled.

The experimental site was fertilized with $102 \mathrm{~kg} / \mathrm{ha}$ of P2O5 and $128 \mathrm{~kg} / \mathrm{ha}$ of $\mathrm{N}$ in $1987 / 1988$, and $65 \mathrm{~kg} /$ ha of $P 2 O 5$ and $140 \mathrm{~kg} / \mathrm{ha}$ of $N$ in 1988/1989.

Soil water content was kept above $60 \%$ of the maximum available water value in the first meter of depth by irrigation (254 $\mathrm{mm}$ in $1987 / 1988$ and $185 \mathrm{~mm}$ in 1988/1989).

The treatments were: an unshaded control, 45 and $55 \%$ shading (determined by means of a line quantum sensor) around flowering (V11-V12/R3), FS; and 45 and $55 \%$ shading during grain filling (R3/R5), GFS. $(\mathrm{V} 11=11$ th leaf, $\mathrm{R} 3=$ milk grain, $\mathrm{R} 5=$ visible dent; Ritchie and Hanway, 1982).

The shading periods were of variable duration (3038 days; table 1) and constant incident radiation (average total irradiation received by the subplots above shading cloth was $721 \mathrm{MJ} / \mathrm{m}^{2}$, CV : $2.2 \%$ ). Plots were shaded with cloths of different mesh, $12 \mathrm{~m}$ long, $2.3 \mathrm{~m}$ wide, stretched on cane and wire structures. Differences of $1-2^{\circ} \mathrm{C}$ in average air temperature between shaded and unshaded plots were recorded.

The experimental design was a split-plot with the hybrids as main plots and shading treatments as sub- plots. The main plots were disposed in randomized complete blocks with four replications in 1987/1988 and three replications in 1988/1989. The subplots consisted of four rows of $12 \mathrm{~m}$ (with one border row on each side). The evolution of total above-ground plant dry weight and its partitioning was followed.

Plant samples were taken every 20-30 days. The sample size was 6 plants in $1987 / 1988$ and 10 plants in $1988 / 1989$. Plants parts were oven-dried at $65^{\circ} \mathrm{C}$ to constant weight, and weighed.

Leaf area was determined using a AAC-400 area meter by Hayashi Denfoh Co Ltd, Japan.

Mean crop growth rate (CGR), net assimilation rate (NAR) and leaf area duration (LAD) were calculated according to Kvet et al (1971) and Gardner et al (1985).

Percent photosynthetically active radiation (PAR) interception by the crop was calculated as $(1-/ / / 0) x$ 100 , where $/$ is the incident PAR at ground level, and 10 is the incident PAR at the top of the canopy. These values were obtained with a LICOR $188 \mathrm{~B}$ radiometer connected to a 191 SB line quantum sensor. Determinations were taken periodically (every 15 days), following the technique described by Gallo and Daughtry (1986) for sensor placement and number of observations. Measurements were confined to $\pm 1 \mathrm{~h}$ from solar noon to eliminate the effect of solar altitude on the interception values. Measurements were taken on sunny days. The PAR intercepted by the shading cloths was calculated by placing the line quantum sensor $15 \mathrm{~cm}$ above and below it. This measurements were taken from 9 am to $4 \mathrm{pm}$.

Stem $\mathrm{CH}$ was determined following the method described by Weinmann (Weinmann, 1947; Berger, 1984). Samplings were taken at the V11-V12, R3; R5 and $R 6$ phenological stages (Ritchie and Hanway, 1982). Each sample consisted of 5 plants (only the ear and the ear-1 internodes were considered; Daynard et al, 1969; Barnett and Pearce, 1983; Jones and Simmons, 1983). These internodes were ovendried at $60^{\circ} \mathrm{C}$ to constant weight and ground $(1-\mathrm{mm}$ mesh screen). Total stem $\mathrm{CH}$ (kg/ha) was calculated as the product of $\mathrm{CH}$ concentration (on dry weight basis) and stem dry weight (Welton et al, 1930; Daynard et al, 1969).

Table I. Phenological stages.

\begin{tabular}{lllllrlrr}
\hline Year & Hybrid & $\begin{array}{l}\text { Sowing } \\
\text { date }\end{array}$ & $\begin{array}{c}\text { Emergence } \\
\text { date }\end{array}$ & $V 11 / N 12$ & $\begin{array}{l}50 \% \\
\text { silking }\end{array}$ & $R 3$ & $R 5$ & $R 6$ \\
\hline \multirow{2}{*}{$87 / 88$} & SPS 240 & $16 / 10$ & $28 / 10$ & $19 / 12(52)$ & $3 / 1(67)$ & $19 / 1(83)$ & $25 / 2(120)$ & $9 / 3(132)$ \\
& D2F11 & $16 / 10$ & $28 / 10$ & $30 / 12(63)$ & $18 / 1(82)$ & $30 / 1(93)$ & $10 / 3(134)$ & $4 / 4(160)$ \\
$88 / 89$ & SPS 240 & $12 / 10$ & $26 / 10$ & $20 / 12(55)$ & $2 / 1(68)$ & $18 / 1(84)$ & $22 / 2(119)$ & $7 / 3(132)$ \\
& D2F11 & $12 / 10$ & $26 / 10$ & $29 / 12(64)$ & $16 / 1(82)$ & $27 / 1(93)$ & $7 / 3(132)$ & $29 / 3(154)$ \\
\hline
\end{tabular}


Stem $\mathrm{CH}$ remobilization to the ear and stem accumulation were calculated as the difference between total stem $\mathrm{CH}$ in R3 and R5. After R5 dry matter losses (tassel parts and the stem top) confound the calculation.

Total $\mathrm{CH}$ remobilization rate was estimated as the ratio between total $\mathrm{CH}$ remobilization and days between R3-R5.

Total $\mathrm{CH}$ remobilization efficiency was calculated as the ratio between total $\mathrm{CH}$ remobilization and stem $\mathrm{CH}$ content in R3. Similar criteria were followed to calculate vegetative dry matter remobilization.

Potential kernel number/ear was visually recounted on 3 ears/subplot at flowering by means of a magnifying glass. Two rows of $7.15 \mathrm{~m}$ length were harvested, and grain moisture recorded. Grain yield $(14 \%$ moisture) and grain yield components were determined.

Harvest index $(\mathrm{HI})$ was calculated as the quotient between grain yield (on dry basis) and total aboveground dry matter.

\section{RESULTS AND DISCUSSION}

Table II shows temperature and radiation data for the different phenologic periods, and table I shows the phenological stages for both years.

Total incident solar radiation was similar both years. Mean daily temperatures were higher in the second than in the first season at all the phenological stages.
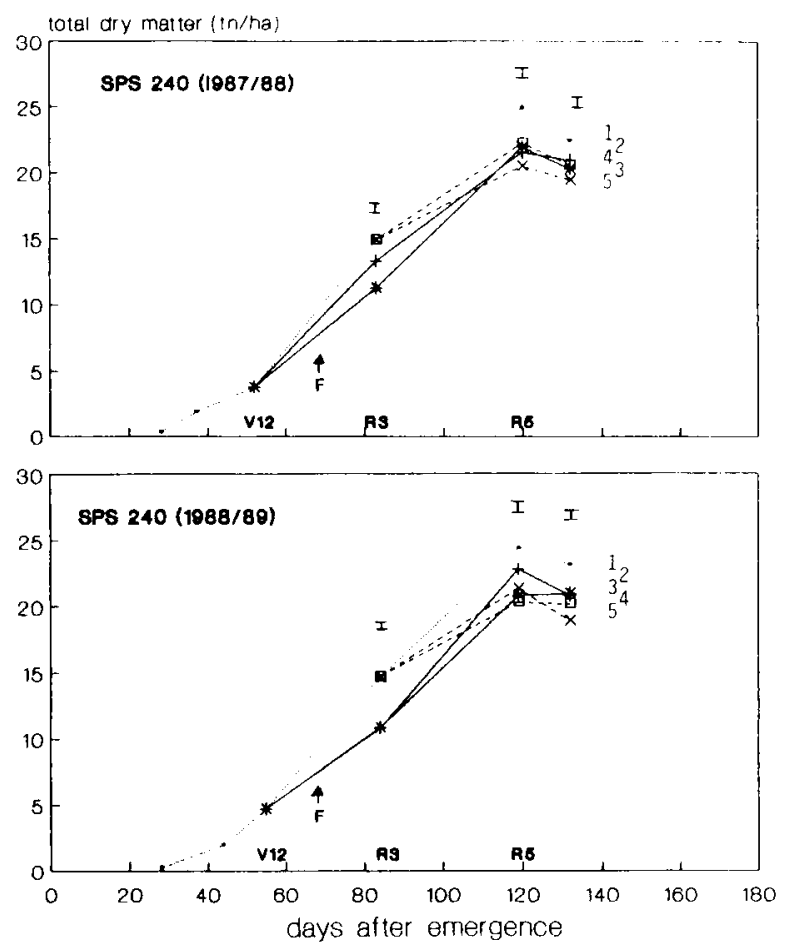

\section{Crop growth and development}

Total above-ground dry matter accumulation was, up to $R 5$, a function of the incident radiation (fig 1). Dry matter losses occurred between R5R6 (senescent leaves, panicles, etc). The lowest values of total dry matter accumulation corresponded to treatment GFS $55 \%$. This is explained by the lowest ear dry matter accumulation in this treatment.

Shading around flowering reduced assimilate partitioning to the ear during the reproductive growth in relation to the control treatment (fig 2), and largely increased reserves in stem + sheaths (fig 3), and to a lower extent in leaves (fig 4) during the grain filling period.

From $R_{3}$ to $R_{5}$, crop growth rates of the FS treatments were similar to those of the control.

Shading around flowering produced a reduction in the number of grains/unit area (table III). The stem became an important sink, accumulating large amounts of carbohydrates (figs 3 and 5). Conversely, shading during the grain filling period induced a great remobilization of reserves from stems generated by the unbalanced relationship between the demand for assimilates by the reproductive sinks and the crop photosynthetic rate. Similar trends were reported by Tollenaar and Daynard (1982), Barnett and Pearce (1983), and Reed et al (1988).
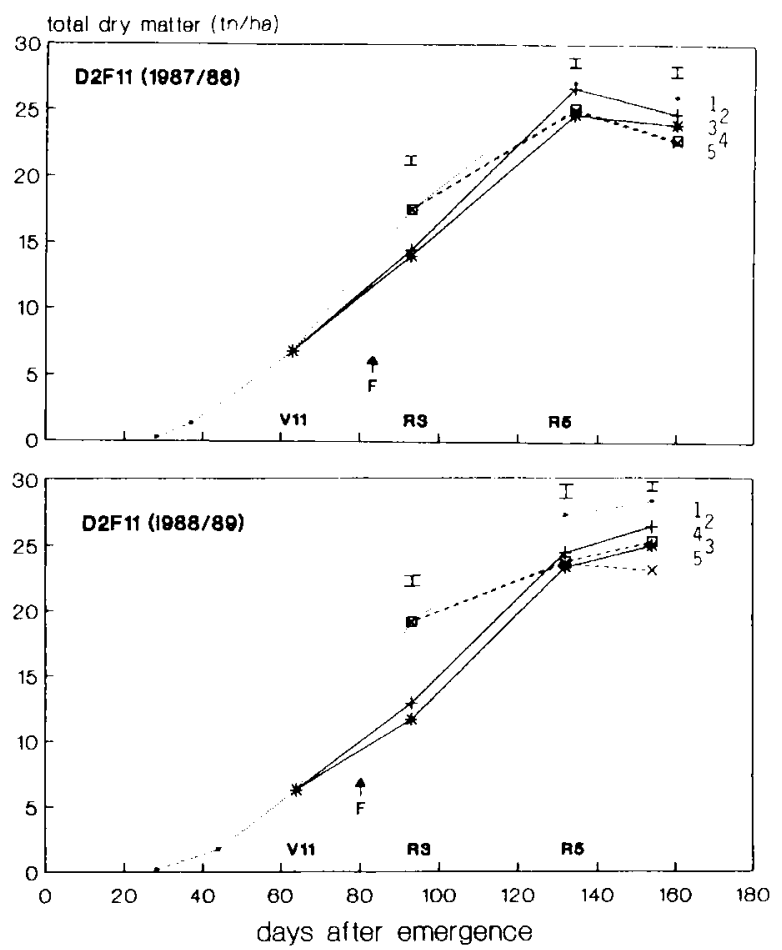

Fig 1. Evolution of above-ground total dry matter for two hybrids, five shading treatments and two growing seasons. Bars indicate the

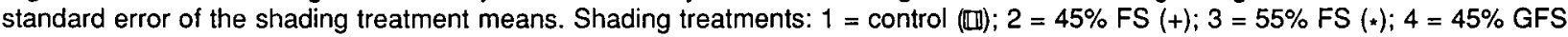
(口) $; 5=55 \%$ GFS $(x)$. 


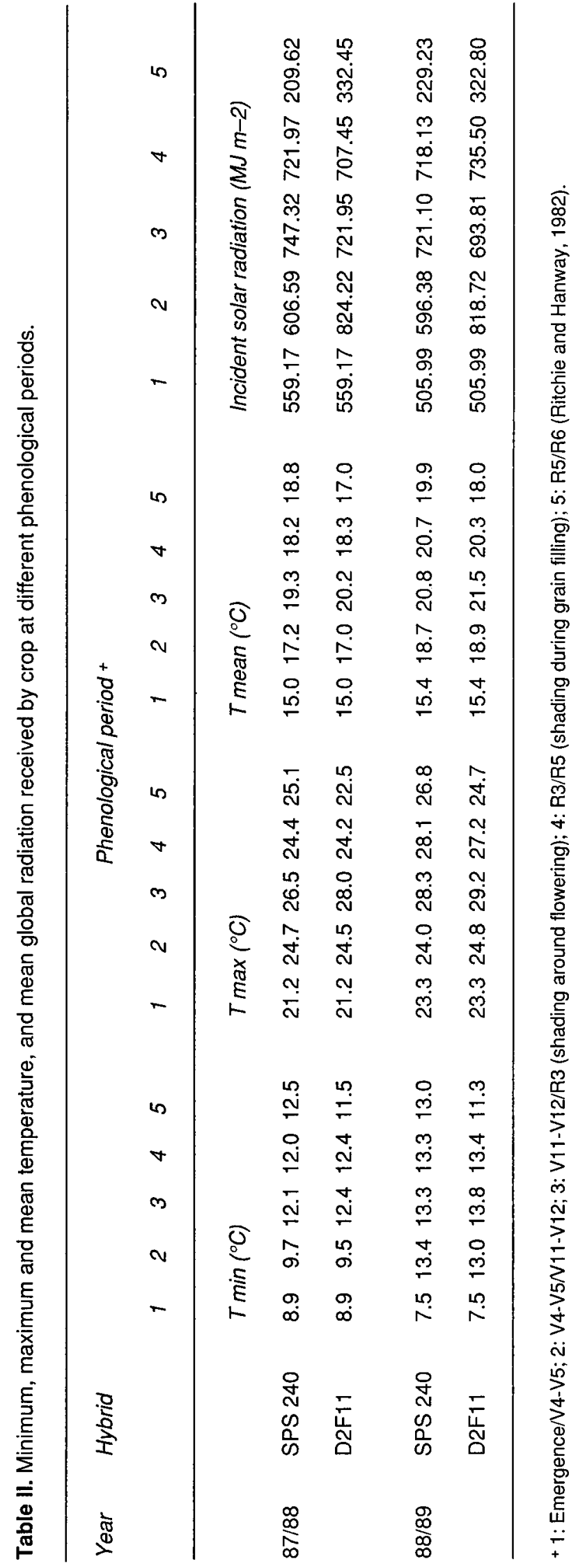



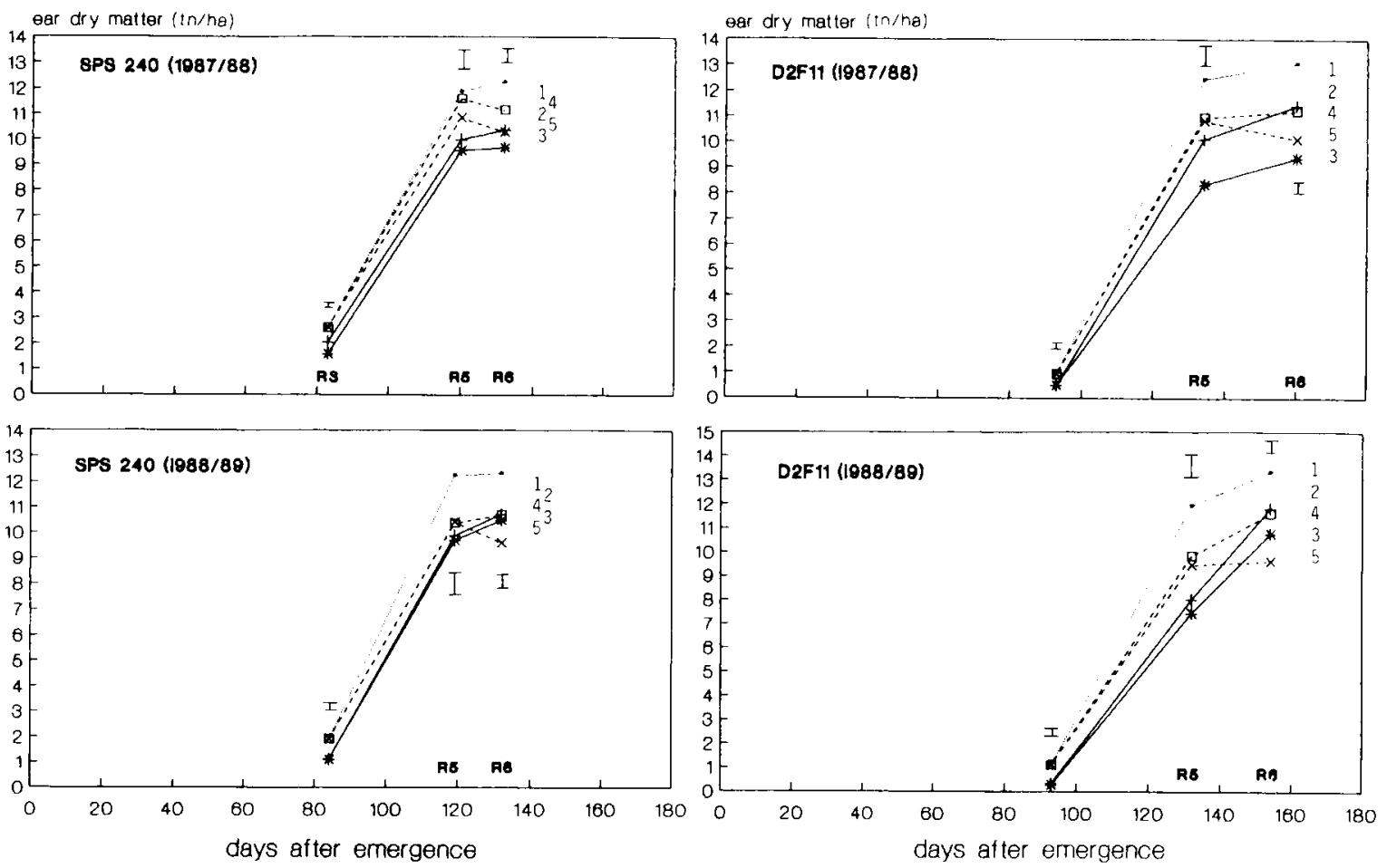

Fig 2. Evolution of ear dry matter for 2 hybrids, 5 shading treatments and 2 growing seasons. Bars indicate the standard error of the shading treatment means. Shading treatments : $1=$ control ( $\square) ; 2=45 \%$ FS $(+) ; 3=55 \%$ FS $(*) ; 4=45 \%$ GFS $(\square) ; 5=55 \%$ GFS (x).
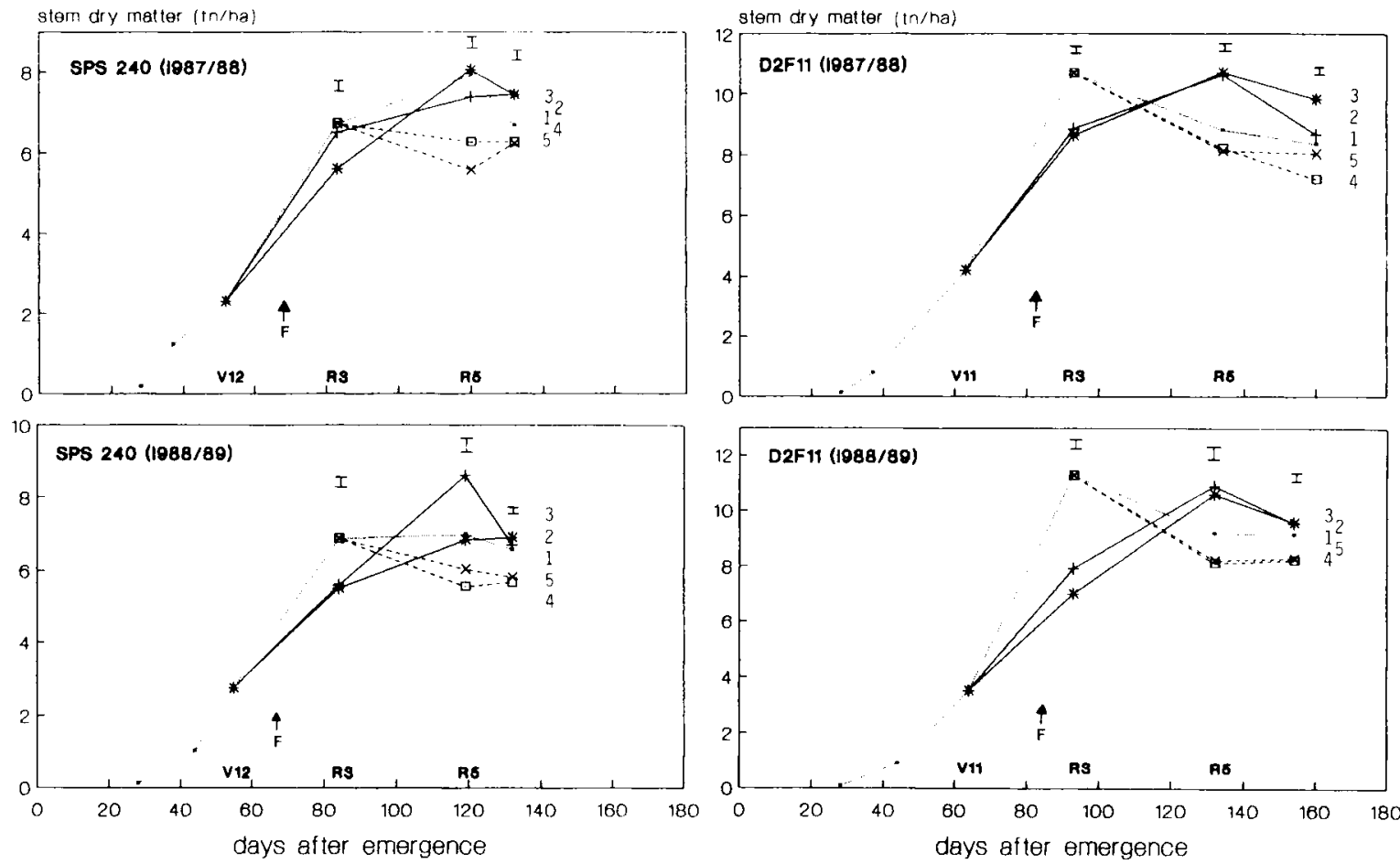

Fig 3. Evolution of stem + sheath dry matter for 2 hybrids, 5 shading treatments and 2 growing seasons. Bars indicate the standard error of the shading treatment means. Shading treatments: $1=$ control (D); $2=45 \%$ FS (+); $3=55 \%$ FS ("); $4=45 \%$ GFS (D); $5=$ $55 \%$ GFS $(x)$. 

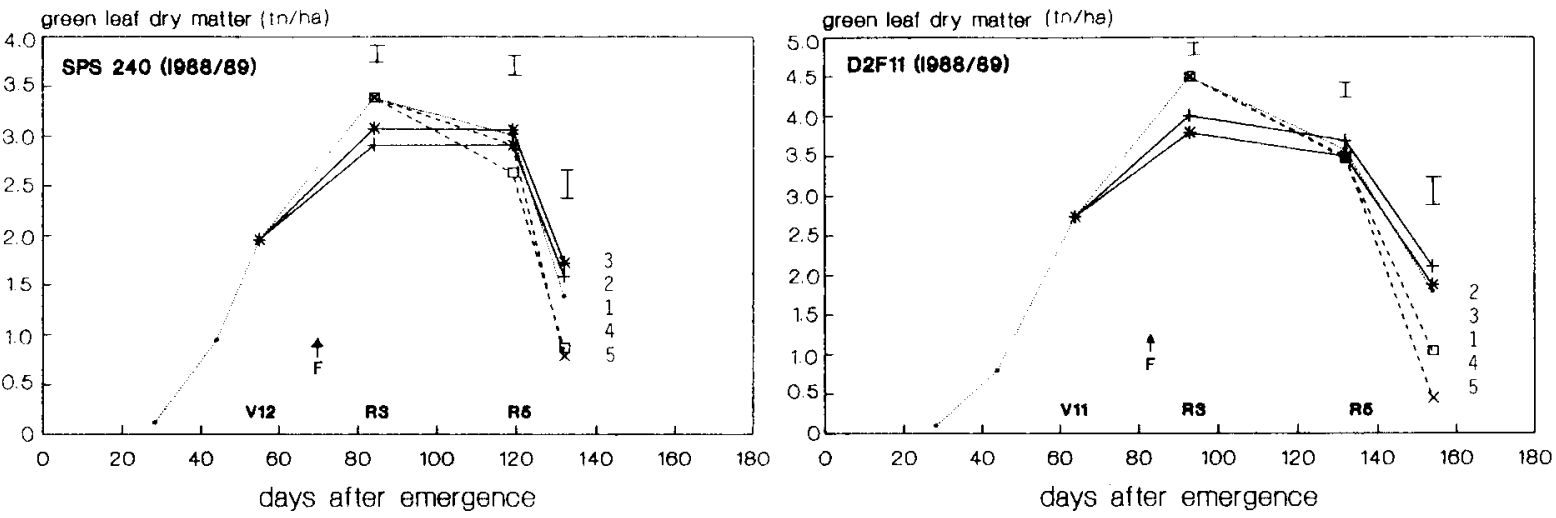

Fig 4. Evolution of green leaf dry matter for 2 hybrids and 5 shading treatments in 1988/1989 growing season (the growing cycle $1987 / 1988$ was similar to second year). Bars indicate the standard error of the shading treatment means. Shading treatments : $1=$ control ( $\square) ; 2=45 \%$ FS $(+) ; 3=55 \%$ FS $(*) ; 4=45 \%$ GFS $(\square) ; 5=55 \%$ GFS $(x)$.

During the R3-R5 period the stem dry matter of the control treatment showed an increase for hybrid SPS 240 and a drastic reduction for hybrid $\mathrm{D} 2 \mathrm{~F} 11$. This provides evidence of the predominance of source or sink limitation.

Dry matter accumulation in green leaves (fig 4; only one-year data are shown since both seasons presented similar results for this variable) presented similar trends to those found for the evolution of stem + sheaths dry matter. Leaf dry
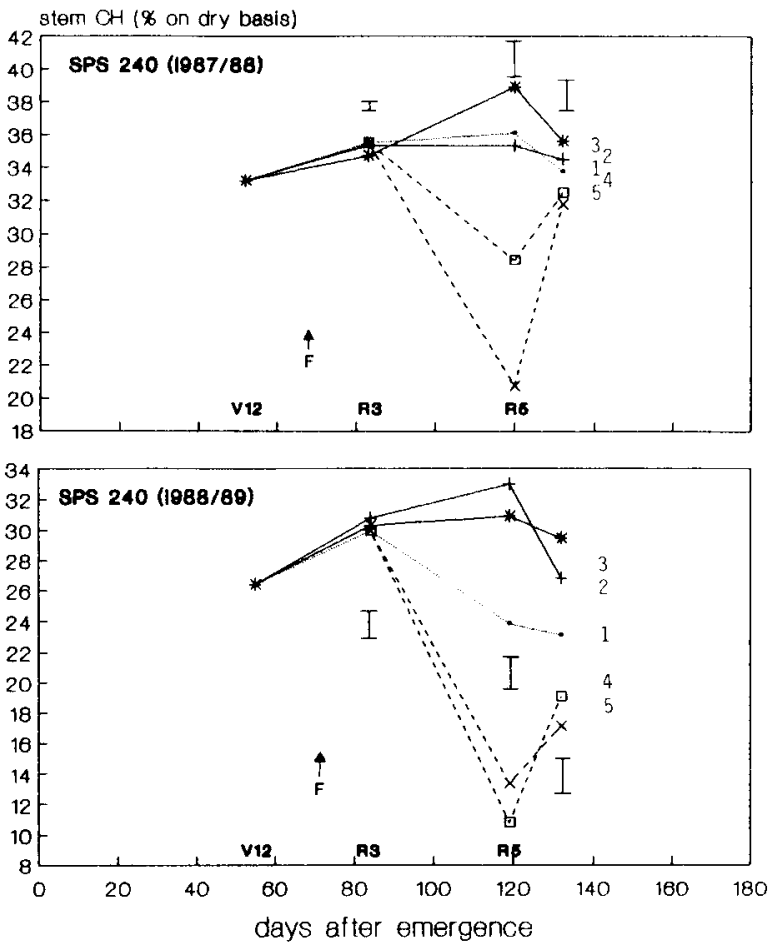

matter diminished during the flowering shading with respect to the control, but it surpassed the latter after that shading period. Two reasons would explain this phenomenon: a) since shading at flowering generated a lower number of reproductive sinks, part of the photosynthates went to alternative sinks; however, the leaves are not an important $\mathrm{CH}$ reservoir in maize; b) the lower number of grains reduced the $\mathrm{CH}$ and $\mathrm{N}$ remobilization, producing a greater leaf area
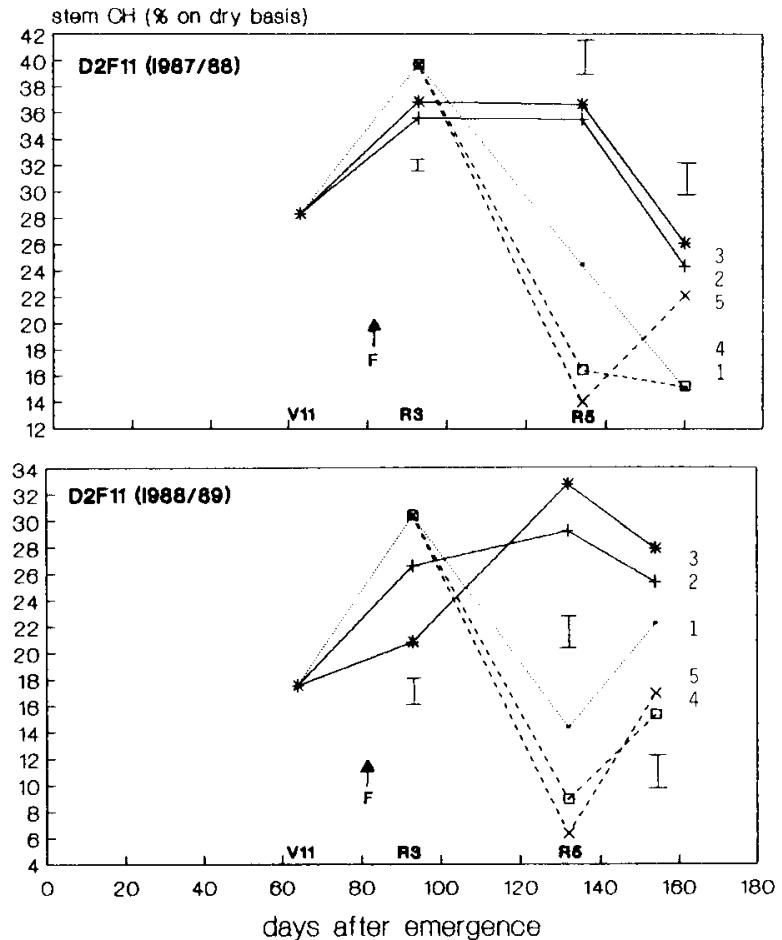

Fig 5. Evolution of stem non-structural carbohydrates of 2 hybrids, 5 shading treatments and 2 growing seasons. Bars indicate the standard error of the shading treatment means. Shading treatments : $1=$ control( $\square) ; 2=45 \%$ FS $(+) ; 3=55 \%$ FS $(*) ; 4=45 \%$ GFS (Đ); $5=55 \%$ GFS $(x)$. 
Table III. Grain yield and yield components (percent values relative to control of each hybrid).

\begin{tabular}{|c|c|c|c|c|c|c|c|c|c|}
\hline \multirow{2}{*}{$\begin{array}{l}\text { Yield } \\
\text { components }\end{array}$} & \multirow[b]{2}{*}{1} & \multirow[b]{2}{*}{2} & \multirow[b]{2}{*}{3} & \multicolumn{3}{|c|}{ Treatment number ${ }^{+}$} & \multirow[b]{2}{*}{$a^{++}$} & \multirow[b]{2}{*}{$b^{++}$} & \multirow[b]{2}{*}{$c^{++}$} \\
\hline & & & & 4 & 5 & $S E$ & & & \\
\hline \multicolumn{10}{|l|}{$87 / 88$ SPS240 } \\
\hline Kernel number & 100 & 84.8 & 78.3 & 98.0 & 93.5 & 2.40 & $x$ & $x x$ & NS \\
\hline Kernel weight & 100 & 99.3 & 100.8 & 93.5 & 90.0 & 1.58 & $x$ & $x x$ & $x$ \\
\hline Grain yield & 100 & 83.9 & 78.6 & 91.4 & 84.3 & 1.93 & NS & $x x$ & $x$ \\
\hline \multicolumn{10}{|l|}{$88 / 89$ SPS 240} \\
\hline Kernel number & 100 & 84.7 & 82.3 & 96.3 & 90.0 & 2.52 & NS & $x x$ & NS \\
\hline Kernel weight & 100 & 103.0 & 103.0 & 90.7 & 87.0 & 2.36 & NS & $x x$ & NS \\
\hline Grain yield & 100 & 86.6 & 84.9 & 87.3 & 78.4 & 2.21 & NS & $x x$ & NS \\
\hline \multicolumn{10}{|l|}{$87 / 88$ D2F11 } \\
\hline Kernel number & 100 & 78.5 & 64.3 & 86.5 & 82.0 & 2.40 & $x$ & $x x$ & NS \\
\hline Kernel weight & 100 & 110.5 & 110.0 & 99.5 & 95.5 & 1.58 & $x$ & $x x$ & $x$ \\
\hline Grain yield & 100 & 86.7 & 70.6 & 85.4 & 77.9 & 1.93 & NS & $x x$ & $x$ \\
\hline \multicolumn{10}{|l|}{$88 / 89$ D2F11 } \\
\hline Kernel number & 100 & 85.0 & 74.3 & 96.0 & 82.0 & 2.52 & NS & $x x$ & NS \\
\hline Kernel weight & 100 & 103.7 & 106.0 & 90.3 & 80.3 & 2.36 & NS & $x x$ & NS \\
\hline Grain yield & 100 & 87.7 & 78.8 & 86.5 & 72.5 & 2.21 & NS & $x x$ & NS \\
\hline
\end{tabular}

+ Treatments: 1 = Control; 2 = FS45\%; 3 = FS55\%; 4 = GFS45\%; $5=$ GFS55\%. ++ a, b, c : significance of differences between hybrids, shading treatments and hybrid $x$ shading treatment interaction (analysis of percentage data was made according to Steel and Torrie, 1960). $x, x x, N S: 5 \%, 1 \%$ significance and no significance respectively.

duration (LAD). This concept is based on the self-destruction theory proposed by Sinclair and de Wit (1976) in soybeans, and on the concepts formulated by Leopold (1961), Moss (1962) and Tollenaar (1986). Significant differences (5\%) in LAD were detected among the treatments during the R5-R6 period for the second growing season. For both hybrids, the values were highest for FS, lowest for GFS and intermediate for the control. The acceleration of senescence under a high source-sink relationship (Christensen et al, 1981 ) is observed as a response to drastic reductions in reproductive sink capacity (for example total ear elimination) that are far from the sink reduction achieved in this experience.

On the other hand, the greater relative demand of the growing kernels in the GFS treatments produced a higher assimilate partition to the grain and a higher $\mathrm{CH}$ and $\mathrm{N}$ remobilization from the leaves during the grain filling period. Similar results were presented by Tollenaar and Daynard (1982) and Reed et al (1988). The FS treatments diminished ear dry matter accumulation (fig 2) and the number of reproductive sinks. Upon removal of the shading cloths at $R 3$, ear growth rate was lower than that of the control and in some cases even lower than that corresponding to GFS.
Since crop growth rates between R3-R5 were similar for the control and FS treatments, it is inferred that the lower number of grains/unit area did not affect the photosynthetic rate but it did modify the assimilate partitioning. The stems, sheaths and husks accumulated more dry matter when the crop was shaded around flowering, while the opposite occurred with the ears. Consequently no evidence of feed-back regulation of photosynthesis by a reduced reproductive sink demand was found.

The GFS treatments reduced ear dry matter accumulation through a reduction in photosynthetic rate. These treatments presented the lowest total dry matter accumulation during the R3R5 period. Upon removal of the shading cloths, the GFS treatments (R5-R6) also presented lower ear growth rate than the rest of the treatments. Similar results were reported by Tollenaar and Daynard (1978) and Reed et al (1988).

This could be explained by the fact that the effective grain filling period was shortened as a response to a low amount of reserves to meet the reproductive sink demand (Daynard and Duncan, 1969; Daynard et al, 1971). The lowest values in green leaves dry matter and $L A D$ observed for these treatments during R5-R6 period of the second year support this concept. 
The FS treatments could have prolonged the effective grain filling period because of the large amount of reserves they had. The crop, stem + sheaths, leaf and ear growth rates, and also the net assimilation rate and vegetative dry matter remobilization (fig 6) showed similar behaviors to that mentioned for total dry matter.

No differences were found among shading treatments in LAI (average range at R3: 4.5-4.8 and 5.9-6.1 for SPS 240 and D2F11, respectively, and average range at R5: $3.8-4.1$ and $4.2-4.7$ for SPS 240 and D2F11, respectively), specific leaf weight and PAR interception. The hybrid D2F11 reached 95\% PAR interception 15 days before flowering while the other hybrid (SPS 240) reached this value around flowering.

The stem $\mathrm{CH}$ values were modified by the shading treatments (fig 5) at all the samplings (except at R3 in the 87/88 growing season). The FS treatments reduced the stem $\mathrm{CH}$ less than the GFS treatments. During the respective shading periods, the GFS treatments produced a greater stem $\mathrm{CH}$ reduction than the $\mathrm{FS}$ treatments. After removing the shades the FS treatments accumulated $\mathrm{CH}$ in the subsequent period to shading (R3-R5). Later, during R5-R6, these $\mathrm{CH}$ were partially remobilized to the ear (photosynthetic rate, air temperature and solar radiation declined, leaf senescence increased, while the grain filling period still continued).

In the GFS treatments the stem $\mathrm{CH}$ were remobilized during the shading period (R3-R5). Upon removal of the shading cloths (R5-R6) they accumulated again in the stems, because of the early ending of the effective grain filling period and the persistence of the assimilate demand by the stem. The evolution of ear and stem dry matter supports this concept.

The reduction in the source of assimilates decreased the grain filling duration, while the reduction in reproductive sink capacity diminished the ear growth rate. The maintenance of the photosynthetic activity in the GFS treatments (with stem $\mathrm{CH}$ accumulation) after the end of the grain filling period, indicates that the finishing signal of grain filling would be produced within the reproductive sinks.

The stem $\mathrm{CH}$ level of the control treatment of hybrid SPS 240 was nearer the maximum possible accumulation than that of hybrid D2F11, while the stem $\mathrm{CH}$ level of the control of D2F11 was nearer the maximum remobilization (GFS) than that of hybrid SPS 240 . The same trends were observed for the $\mathrm{CH}$ remobilization rate and efficiency (tables IV and V). For example, for SPS 240, 1987/1988 growing season, differences between $\mathrm{CH}$ remobilization rate of control treatment and the maximum possible accumulation and remobilization were 39 and $75 \mathrm{~kg} \mathrm{ha}-1$ day-1 respectively (table IV). The control value is nearer the maximum accumulation than the maximum remobilization. There was, therefore, a trend toward a sink limitation.

This information provides more evidence to establish the predominance of source or sink limitation.

\section{Grain yield and yield components}

The effects of plot and subplot treatments are shown in table III. The FS treatment reduced
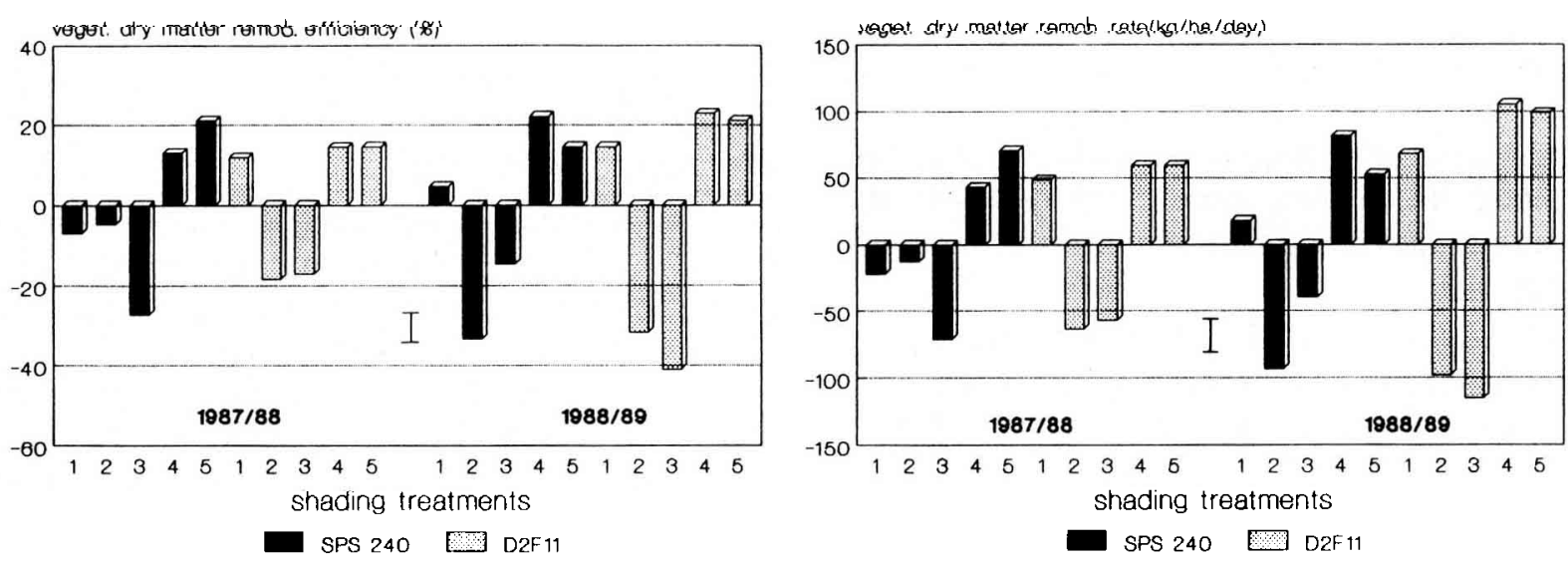

Fig 6. Vegetative dry matter (VDM) remobilization rate ([VDM R3-VDM R5]/ days between R3, R5) and vegetative dry matter remobilization efficiency ([VDM R3-VDM R5]NDM R3), between R3-R5, for 2 hybrids, 5 shading treatments and 2 growing seasons. Bars indicate the standard error of the shading treatment means. Shading treatments : $1=$ control; $2=45 \% \mathrm{FS} ; 3=55 \% \mathrm{FS} ; 4=$ $45 \%$ GFS $; 5=55 \%$ GFS. 
Table IV. Comparison between the maximum values (for the trial conditions) and control treatment values of total stem $\mathrm{CH}$ remobilization and accumulation rate $\left(\mathrm{kg} \mathrm{ha}^{-1}\right.$ day $\left.^{-1}\right)$ during $\mathrm{R} 3-\mathrm{R} 5$ period.

\begin{tabular}{|c|c|c|c|c|c|c|c|c|}
\hline \multirow{3}{*}{$\begin{array}{l}\text { Year } \\
\text { Treatment }\end{array}$} & \multicolumn{4}{|c|}{ SPS 240} & \multicolumn{4}{|c|}{$D 2 F 11$} \\
\hline & \multicolumn{2}{|c|}{ Accumulation } & \multicolumn{2}{|c|}{ Remobilization } & \multicolumn{2}{|c|}{ Accumulation } & \multicolumn{2}{|c|}{ Remobilization } \\
\hline & $87 / 88$ & $88 / 89$ & $87 / 88$ & $88 / 89$ & $87 / 88$ & $88 / 89$ & $87 / 88$ & $88 / 89$ \\
\hline & \multicolumn{4}{|c|}{$\mathrm{kg} \mathrm{ha}^{-1}$ day $^{-1}$} & \multicolumn{4}{|c|}{$\mathrm{kg} \mathrm{ha}^{-1}$ day $^{-1}$} \\
\hline Control & +24 & -19 & +24 & -19 & -49 & -60 & -49 & -60 \\
\hline FS or GFS & +63 & +66 & -51 & -71 & +24 & +78 & -73 & -85 \\
\hline Difference & 39 & 85 & 75 & 52 & 73 & 138 & 24 & 25 \\
\hline
\end{tabular}

Values $(+)=$ accumulation $(-)=$ remobilization. $F S=$ flowering shading treatments (accumulation values); GFS = grain filling shading treatments (remobilization values).

Table V. Stem $\mathrm{CH}$ remobilization efficiency ([CH R3-CH R5]/CH R3) during R3-R5 period.

\begin{tabular}{|c|c|c|c|c|c|c|c|c|c|c|}
\hline \multirow{2}{*}{$\begin{array}{l}\text { Treatment } \\
\text { Year }\end{array}$} & \multicolumn{5}{|c|}{ +SPS 240} & \multicolumn{5}{|c|}{$D_{2 F 11}$} \\
\hline & 1 & 2 & 3 & 4 & 5 & 1 & 2 & 3 & 4 & 5 \\
\hline & & & $\%$ & & & & & $\%$ & & \\
\hline $87 / 88$ & -0.24 & -0.19 & -0.63 & 0.24 & 0.51 & 0.49 & -0.21 & -0.24 & 0.67 & 0.73 \\
\hline $88 / 89$ & 0.19 & -0.66 & -0.30 & 0.71 & 0.60 & 0.60 & -0.54 & -0.78 & 0.79 & 0.85 \\
\hline Average & -0.02 & -0.43 & -0.46 & 0.48 & 0.56 & 0.55 & -0.38 & -0.51 & 0.73 & 0.79 \\
\hline
\end{tabular}

Negative values indicate $\mathrm{CH}$ accumulation. Standard error: $87 / 88=0.09 ; 88 / 89=0.16$. + Treatments: $1=$ Control $2=\mathrm{FS} 45 \% ; 3=$ FS55\%; 4 = GFS $45 \% ; 5$ = GFS $55 \%$.

grain number/unit area and increased kernel weight. The GFS treatment reduced grain weight and to a lesser extent grain number/unit area. In the $1987 / 1988$ growing season the second ear abortion (extended to a middle of grain filling period) reduced to a greater extent the grain number/ha. The plant response under a source limjtation was, in this case, to eliminate the second ears more than reduce the grain weight. No differences in potential number of grain/ear (at flowering) was found between the shading treatments.

The kernel weight of the control treatment of hybrid SPS 240 was closer to its potential weight (for the conditions of the trial) than that of hybrid D2F 11 .

No differences were detected in grain yield (Tukey test $5 \%$ ) between shading at flowering and during grain filling (table $\mathrm{VI}$ ). The combined year analysis shows a significant interaction year $x$ shading treatment.
The harvest index $(\mathrm{HI})$ was higher for the control, intermediate for the GFS treatments and lower for the FS treatments. These results agree with the accumulation and remobilization trends observed for those treatments.

The impact of shading during flowering on the reproductive sinks and that of shading during grain filling on the source of the assimilates were proportionally similar.

In Balcarce, grain yield is colimited by the source of assimilates during grain filling and by the reproductive sink capacity. According to the methodology proposed by Tollenaar (1977) and Tollenaar and Daynard (1978) the grain yield was affected in the same proportion by a reduction in the assimilate flux around flowering and during the grain filling period (table VI). The kernel weight of the SPS 240 control treatment was closer to its potential weight (for the conditions of the experiment) than that of the D2F11 hybrid. This fact is evidence that the SPS 240 hybrid 
Table VI. Grain yield for the different treatments (kg/ha, 14\% moisture).

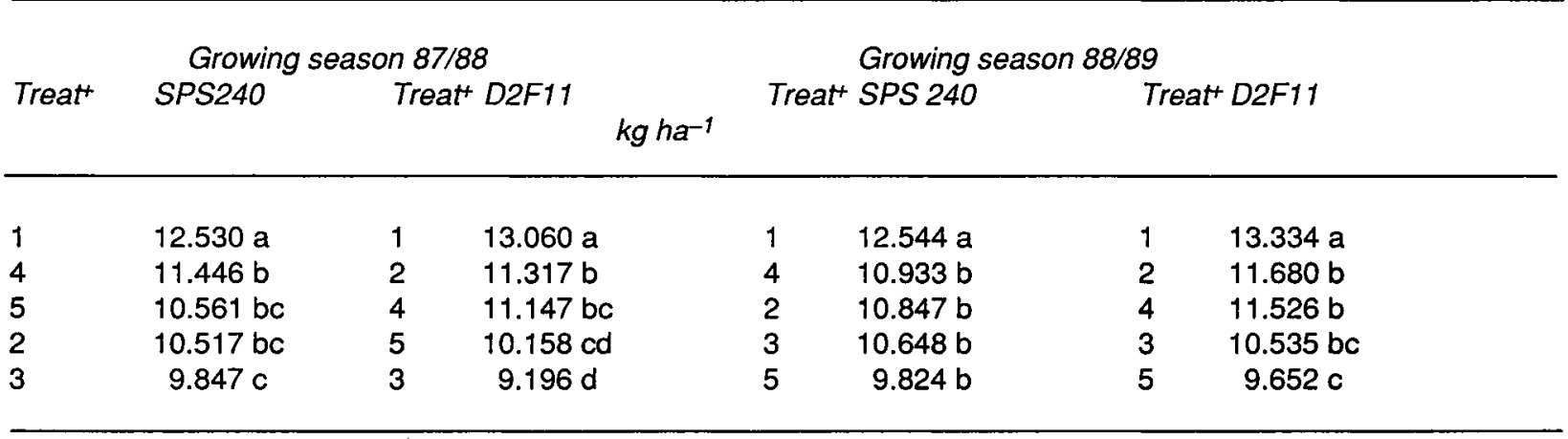

Standard error to compare shading treatments: $87 / 88=253 \mathrm{~kg} / \mathrm{ha} ; 88 / 89=294.6 \mathrm{~kg} / \mathrm{ha}$. The same letters indicate no differences between shading treatments (Tukey test 5\%). + Treatments: 1 = Control; $2=$ FS $45 \% ; 3=$ FS55\%; $4=$ GFS $45 \% ; 5=$ GFS55\%.

presented a stronger trend towards a sink limitation than the other hybrid.

Other variables provided evidence for the predominant limitation within the colimitation.

During the R3-R5 period, stem dry matter was constant or increased during the two growing seasons in the control treatment of SPS 240 hybrid. The assimilate production exceeded the grain capacity to accomodate them, indicating a tendency toward a sink limitation. In contrast, substantial remobilization of stem dry matter occurred for D2F11 in both years. This indicates a tendency toward a source limitation within the colimitation. The actual photosynthesis was not enough to satisfy the demand of the developing grains, that used, in consequence, part of the stored stem reserves.

The rate and efficiency of the vegetative dry matter remobilization supported the trends to a source or sink limitation shown by the hybrids D2F11 and SPS 240, respectively. The stem $\mathrm{CH}$ evolution of the control treatment showed accumulation or light remobilization for SPS 240 , and strong remobilization for D2F11. The remobilization rate and efficiency showed similar results.

In both years, the control treatments were away of the maximum possible accumulation (FS) or remobilization (GFS) measured in the experience, indicating the presence of both limitations. However, SPS 240 was closer to the maximum accumulation (sink limitation trend) and D2F11 closer to the maximum possible remobilization observed in the experiment (source limitation trend).

Then, Balcarce presents environmental conditions that place it in an intermediate position with respect to the tropics (that presents a net repro- ductive sink capacity limitation for grain yield) and Canada (that presents a source limitation).

\section{CONCLUSIONS}

The results indicate the existence of a colimitation by source of assimilates and reproductive sinks because grain yield dropped similarly in response to shading during the flowering and the grain filling periods.

FS reduced the grain number/unit area and slightly increased the 1000 kernel weight. GFS reduced the 1000 kernel weight, and to a lesser extent, the grain number/unit area.

Shading at any period produced, relative to the control, a decrease in stem $\mathrm{CH}$ content during the time of treatment imposition. The FS treatments presented, during the post-shading period, a greater $\mathrm{CH}$ accumulation in stems than the control. This is explained by the decrease of reproductive sink number that produced a drop in their demand of $\mathrm{CH}$ and by the increased importance of the stem as an alternative sink for assimilates. GFS treatments produced a strong increase in $\mathrm{CH}$ remobilization rate from stem during the time of treatment imposition.

The two hybrids did not show statistically significant differences in their source-sink relationships. Nevertheless, a tendency towards a source limitation was evident in the long season hybrid.

\section{REFERENCES}

Allison JCS, Watson DJ (1966) The production and distribution of dry matter in maize after flowering. Ann Bot 30, 365-381 
Allison JCS, Wilson JHH, Williams JH (1975) Effect of defoliation after flowering on changes in stem and grain mass of closely and widely spaced maize. Rhod J Agric Res 13, 145-147

Barnett KH, Pearce RB (1983) Source-sink ratio alteration and its effect on physiological parameters in maize. Crop Sci 23, 294-299

Berger ME (1984) Metodo de Weinmann para la determinacion de los carbohidratos totales no estructurales en alfalfa: comparacion de tres metodos de filtracion del hidrolizado. Rev Invest Agrop 19, 139147

Bingham J (1967) Investigation on the physiology of yield in winter wheat by comparison of varieties and by artificial variation in grain number per ear. $\mathrm{J} \mathrm{Ag}$ ric Sci Camb 68, 411-422

Brown DM (1969) Heat Units for Corn in Southern Ontario. Ontario Department of Agriculture and Food, Canada, p 4

Christensen LE, Below FE, Hageman RH (1981) The effects of ear removal on senescence and metabolism of maize. Plant Physiol 68, 1180-1181

Daynard TB, Duncan WG (1969) The black layer and grain maturity in corn. Crop Sci 9, 473-476

Daynard TB, Tanner JW, Hume DJ (1969) Contribution of stalk soluble carbohydrates to grain yield in corn (Zea mays L). Crop Sci 9, 831-834

Daynard TB, Tanner JW, Duncan WG (1971) Duration of the grain filling period and its relation to grain yield in corn, Zea mays L. Crop Sci 11, 45-48

Early EB, Miller RJ, Reichert GL, Hageman RH, Seif RD (1966) Effects of shade on maize production under field conditions. Crop Sci 6, 1-7

Early EB, Mcllrath WO, Seif RD, Hageman RH (1967) Effects of shade applied at different stages of plant development on corn (Zea mays L) production. Crop Sci 7, 151-156

Evans L, Rawson HM (1970) Photosynthesis and respiration by the flag leaf and components of the ear during grain development in wheat. Aust $J$ Biol Sci 23, 245-254

Fischer RA (1975) Yield potential in a dwarf spring wheat and the effect of shading. Crop Sci 15,607613

Gallo KP, Daughtry CST (1986) Techniques for measuring intercepted and absorbed photosynthetically active radiation in corn canopies. Agron $J 78,752$ 756

Gardner FP, Pearch RB, Michell RL (1985) Physiology of Crop Plants. lowa State University Press. Ames, USA

Goldsworthy PR, Coleogrove M (1974) Growth and yield of highland maize in Mexico. $J$ Agric Sci Camb 83, 213-221

Goldsworthy PR, Palmer AFE, Sperling DW (1974) Growth and yield of lowland tropical maize in Mexico. J Agric Sci Camb 83, 223-230
Hanway JJ (1969) Defoliation effects on different corn (Zea mays L) hybrids as influenced by plant population and stage of development. Agron J61, 534-538

Hicks DR, Nelson WW, Ford JH (1977) Defoliation effects on corn hybrids adapted to the northern corn belt. Agron J 60, 387-390

Hume DJ, Campbell DK (1972) Accumulation and translocation of soluble solids in corn stalks. Can J Plant Sci 52, 363-368

Jones RJ, Simmons SR (1983) Effect of altered source-sink ratio on growth of maize kernels. Crop Sci 23, 129-134

Kvet J, Ondok JP, Necas J, Jarvis PG (1971) Methods of Growth Analysis (Sestak Z, Catsky J, Jarvis PG, eds) Dr W Junk NV, The Hague, 343-384

Lauer MJ (1985) Soybean leaf response to changing sink demand. MS Thesis. lowa State University, $p$ 60

Leopold AC (1961) Senescence in plant development. The death of plants or plants parts may be a positive ecological or physiological value. Science 134 , 1727-1732

Moss DN (1962) Photosynthesis and barrenness. Crop Sci 2, 366-367

Prine GM (1971) A critical period for ear development in maize. Crop Sci 11, 782-786

Reed AJ, Singletary GW, Schussler JR, Williamson DR, Christy AL (1988) Shading effects on dry matter and nitrogen partinioning, kernel number, and yield of maize. Crop Sci 28, 819-825

Ritchie SW, Hanway JJ (1982) How a Corn Plant Develops. lowa State University, Spec Rep N 48, p 21

Schoper JB, Johnson RR, Lambert RJ (1982) Maize yield response to increased assimilate supply. Crop Sci 22, 1184-1189

Sinclair TR, de Wit CT (1976) Analysis of the carbon and nitrogen limitations to soybean yield. Agron $J$ $68,319-324$

Simpson GM (1968) Association between grain yield per plant and photosynthetic area above the flag leaf node in wheat. Can J Plant Sci 48, 253-260

Steel RG, Torrie JH (1960) Principles and Procedures of Statistics. A Biometrical Approach. Mc Graw-Hill Book Co, New York

Stoy $V(1976)$ Source and sink properties as related to yield in different barley genotypes. Proc 3rd International Barley Genetics Symposium, 641-648

Tollenaar M (1977) Sink-source relationships during reproductive development in maize. A review. Maydica 22, 49-75

Tollenaar M (1986) Effect of assimilate partitioning during the grain filling period of maize on rate of dry matter accumulation. Proc 3rd International Conference on Phloem Transport, California, USA, 551556 
Tollenaar M, Daynard TB (1978) Relationship between assimilate source and reproductive sink in maize grown in short-season environment. Agron $J 70$, 219-223

Tollenaar M, Daynard TB (1982) Effect of sourcesink ratio on dry matter accumulation and leaf senescence of maize. Can J Plant Sci 62, 855-860

Vasilas VL, Seif RD (1985) Pre-anthesis defoliation effects on six corn inbreds. Agron J 77, 831-835

Weinmann H (1947) Determination of total available carbohydrates in plants. Plant Physiol 22, 279-290
Welbank PJ, French SAW, Witts KJ (1966) Dependence of yields of wheat varieties on their leaf area duration. Ann Bot NS 30, 291-299

Welton FA, Morris VH, Hartzler AJ (1930) Distribution of moisture, dry matter and sugars in the maturing corn stem. Plant Physiol 5, 555-564

Yamaguchi $J(1974)$ Varietal traits limiting the grain yield of tropical maize. IV. Plant traits and productivity of tropical varieties. Soil Sci Plant Nutr 20, 287-304

Yoshida S (1972) Physiological aspects of grain yield. Annu Rev Plant Physiol 23, 437-464 